\title{
On a grain of sand - a microhabitat for the opportunistic agglutinated foraminifera Hemisphaerammina apta n. sp., from the early Eocene Arctic Ocean
}

\author{
David H. McNeil ${ }^{1}$ and Lisa A. Neville ${ }^{2,3}$ \\ ${ }^{1}$ Geological Survey of Canada, Natural Resources Canada, Calgary, Alberta, T2L 2A7, Canada \\ ${ }^{2}$ Enviro-Verse Ltd., Calgary, Alberta, T2P 2T8, Canada \\ ${ }^{3}$ Department of Earth Sciences, Brock University, St. Catharines, Ontario, L2S 3A1, Canada
}

Correspondence: David H. McNeil (dave.mcneil@canada.ca)

Published: 8 February 2018

\begin{abstract}
Hemisphaerammina apta $\mathrm{n}$. sp. is an attached monothalamous agglutinated foraminifera discovered in shelf sediments of the early Eocene Arctic Ocean. It is a simple yet distinctive component of the endemic agglutinated foraminiferal assemblage that colonized the Arctic Ocean after the microfaunal turnover caused by the Paleocene-Eocene Thermal Maximum. Associated foraminifera are characterized by a high percentage of monothalamous species (up to 60\%) and are entirely agglutinated indicating a brackish (mesohaline) early Eocene Arctic Ocean. Hemisphaerammina apta occurs exclusively as individuals attached to fine detrital grains ( 0.2 to $1.8 \mathrm{~mm}$ ) of sediment. It is a small species ( 0.06 to $0.2 \mathrm{~mm}$ in diameter), fine-grained, with a low hemispherical profile, no floor across the attachment area, no substantive marginal flange, no internal structures, and no aperture. Lacking an aperture, it apparently propagated and fed through minute (micrometre-sized) interstitial pores in the test wall. Attachment surfaces vary from concave to convex and rough to smooth. Grains for attachment are diverse in shape and type but are predominantly of quartz and chert. The presence of $H$. apta in the early Eocene was an opportunistic response to an environment with an active hydrological system (storm events). Attachment to grains of sand would provide a more stable base on a sea floor winnowed by storm-generated currents. Active transport is indicated by the relative abundance of reworked foraminifera mixed with in situ species. Contemporaneous reworking and colonization by $H$. apta is suggested by its attachment to a reworked specimen of Cretaceous foraminifera.
\end{abstract}

\section{Introduction}

Cenozoic foraminifera from the Arctic Beaufort-Mackenzie area have been documented over the last few decades (McNeil, 1996, figs. 70, 71, 1997). Current work is now in progress on more detailed and comprehensive taxonomic study of the early Eocene agglutinated taxa, with an emphasis on the monothalamous component of the assemblages. Our present paper, however, focuses on one particular monothalamous taxon that stands apart from other species because of its exceptional microhabitat. Hemisphaerammina apta $\mathrm{n}$. sp. is an attached monothalamous agglutinated foraminifera, which occurs as individuals, or in groups of individuals, that occupied an extremely localized micro- habitat of attachment on fine detrital grains of sand in marine shelf environments (Plate 1).

Hemisphaerammina apta is a component of an Eocene endemic foraminiferal assemblage that appeared in the Arctic Ocean after the climatic events and foraminiferal extinctions associated with the Paleocene-Eocene Thermal Maximum (PETM) (McNeil and Parsons, 2013). Geographic isolation and climatic factors combined to foster this endemism and produce a foraminiferal assemblage that differs substantially from cosmopolitan Eocene assemblages as, for example, monographed by Kaminski and Gradstein (2005). The primary driver behind this endemism was the restriction of the Arctic Ocean, i.e. the complete closure to the Pacific and limited shallow water connections to the North 


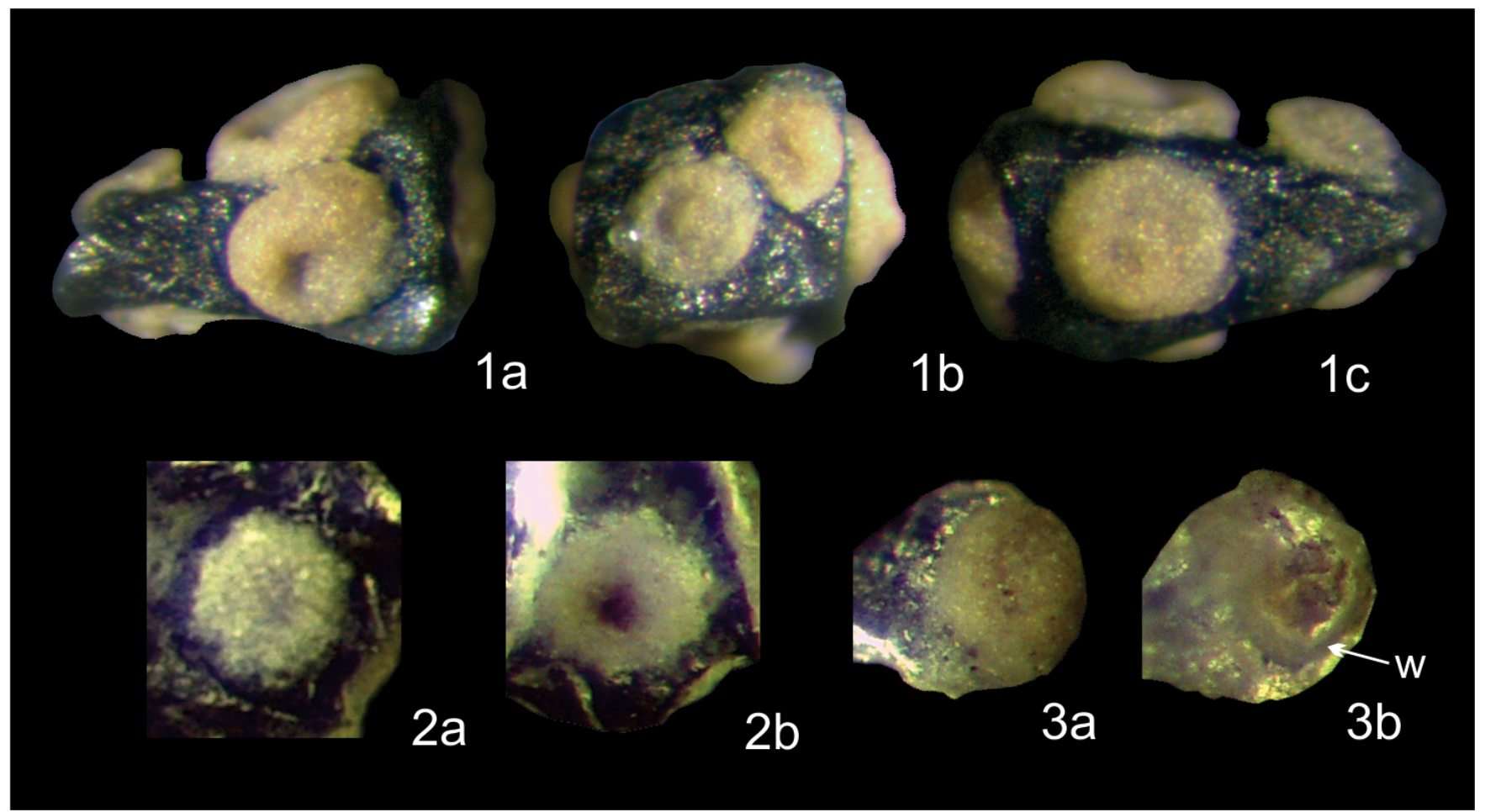

Plate 1. Optical reflected light images of Hemisphaerammina apta n. sp. from the Natsek E-56 exploration well, Beaufort Sea, Arctic Canada. (1a-c) Specimens of $H$. apta attached to a chert grain (length $\sim 0.54 \mathrm{~mm}$ ), $4600 \mathrm{ft}$ (1402 m), paratype GSC 1336673: (1a) lateral view; (1b) end view; (1c) lateral view. (2a, b) H. apta (diameter $158 \mu \mathrm{m}$ ) attached to a quartz grain, $4600 \mathrm{ft}$ (1402 m), paratype GSC 1336674 : (2a) dorsal view; (2b) ventral view through clear quartz showing brown matter filling the chamber lumen. (3a, b) H. apta (diameter 215 $\mu$ m) attached to a quartz grain, $5000 \mathrm{ft}(1524 \mathrm{~m})$, paratype GSC 1336675: (3a) dorsal view; (3b) ventral view through clear quartz showing ring-shaped outline of attached wall $(\mathrm{w})$ and darker matter in the lumen.

Atlantic (Sluijs et al., 2006; Pagani et al., 2006). Secondly, but just as important, a wet early Eocene climate provided a vigorous hydrological system with a heavy input of fresh water into this restricted ocean basin (Barron et al., 1989; Brinkhuis et al., 2006). These conditions created low-salinity marine shelf environments, which were probably mesohaline, based on the presence and composition of agglutinated foraminifera and the absence of calcareous benthic and planktonic foraminifera (McNeil and Parsons, 2013). Locally, i.e. in the Beaufort-Mackenzie area, a third factor of rapid deltaic sedimentation influenced the biotic record (Dixon et al., 1992).

Hemisphaerammina is an attached sessile genus (Loeblich Jr. and Tappan, 1957). Attachment is a common habit for foraminifera, and there are several mechanisms for attachment such as pseudopodia, organic cement, and mineral secretion. Substrates for attachment typically are rocks, molluscs, plants, corals, crinoids, brachiopods, sponges, crustaceans, hardgrounds, nodules, worm tubes, radiolarians, and other foraminifera (Goineau and Gooday, 2015; Guilbault et al., 2006; Jonasson and Schröder-Adams, 1996; Langer, 1993; Langer and Bagi, 1994; Langer and Long, 1994; Plint et al., 2006; Poag, 1982; Radford et al., 2014; Resig and
Glenn, 1997; Richardson-White and Walker, 2011). Attachment provides stability for food acquisition in an environment that is subject to currents and suspended ephemeral food sources. Resig and Glenn (1997) summarized that attached foraminifera generally have three things in common: firm substrates, low sediment accumulation rates, and good water circulation; however, this only partially applies to H. apta.

Hemisphaerammina is represented by relatively few species, but it has a long geological record from the middle Cambrian to the Holocene (Cherchi and Schroeder, 1985; Loeblich Jr. and Tappan, 1988). The shape of the test is approximately hemispherical with no chamber floor across the attachment area. Some species have a flange extended out from the edge of the dome, and this would enhance the security of attachment. Hemisphaerammina lacks an aperture. This is assumed to be a primitive feature (Mikhalevich and Debenay, 2001) but is an unusual development considering how fundamental an aperture is in the vast majority of foraminifera. Loeblich and Tappan (1988) noted that communication externally (i.e. feeding) would have been accomplished through interstitial pores in the agglutinated wall. The asexual life cycle of $H$. crassa was studied in an early 


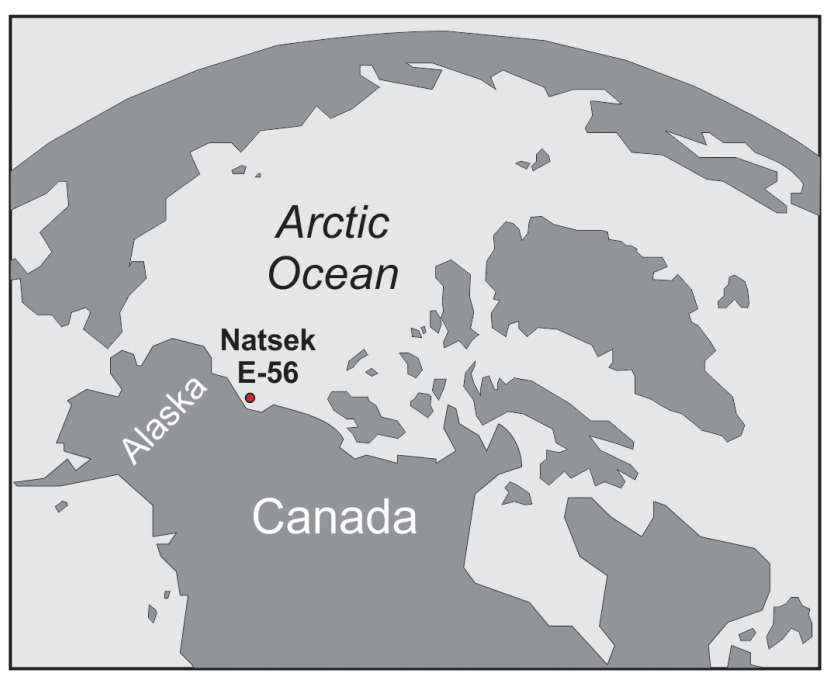

Figure 1. Arctic Ocean index map showing location of the Natsek $\mathrm{N}-56$ exploration well sample locality in the Beaufort Sea, Canada.

work by Le Calvez (1938), who illustrated its biflagellate gametes $(\sim 5 \mu \mathrm{m}$ in diameter). Alve (1999) considered that dispersal in attached foraminifera would most likely occur through the release and transport of embryonic juveniles.

Our study was undertaken as a starting point to describe early Eocene foraminifera from the Arctic Ocean and understand them in terms of response to the major climatic changes of the time. Early Eocene foraminifera are largely endemic in the semi-enclosed Arctic Ocean, and the assemblages display other unique characteristics, such as species composition and an overwhelming dominance by agglutinated foraminifera (McNeil and Parsons, 2013). Significantly, monothalamous foraminifera constitute up to $60 \%$ of the specimens present in some of the collections from the Beaufort-Mackenzie area. These single-chambered foraminifera have received attention lately because of their basal (primitive) position in the evolutionary history of foraminifera (Goldstein, 2014).

\section{Sampling and methods}

Sample analysis was based on well cuttings from the Dome Pacific et al. PEX Natsek E-56 exploration well situated in the southwestern part of the Canadian Beaufort Sea, Arctic Ocean (lat $69^{\circ} 45^{\prime} 21.46^{\prime \prime} \mathrm{N}$, long $139^{\circ} 44^{\prime} 34.58^{\prime \prime} \mathrm{W}$ ) (Fig. 1). Twelve $100 \mathrm{~g}$ samples from 4200 to $6200 \mathrm{ft}$ (1280$1890 \mathrm{~m}$ ) from the lower part of the early to middle Eocene Taglu sequence were processed and picked for their entire foraminiferal content. Microslides are stored in the collections of the Geological Survey of Canada, Calgary (GSCC).
Table 1. Number of $H$. apta specimens and reworked foraminifera recovered from $100 \mathrm{~g}$ of sediment. Correlation coefficient between $H$. apta and reworked foraminifera is 0.35 , indicating a slight to moderate correlation.

\begin{tabular}{lrrrrr}
\hline & \multicolumn{2}{c}{$\begin{array}{c}\text { Number of specimens } \\
\text { per sample }\end{array}$} & & \multicolumn{2}{c}{$\begin{array}{c}\text { Percentage of total } \\
\text { foraminiferal recovery }\end{array}$} \\
\cline { 2 - 3 } \cline { 5 - 6 } $\begin{array}{l}\text { Depth } \\
\text { (m) }\end{array}$ & $\begin{array}{r}H . \\
\text { apta }\end{array}$ & $\begin{array}{c}\text { Reworked } \\
\text { foraminifera }\end{array}$ & & $\begin{array}{r}H . \\
\text { apta }\end{array}$ & $\begin{array}{r}\text { Reworked } \\
\text { foraminifera }\end{array}$ \\
\hline 1280 & 3 & 0 & & 1.04 & 0 \\
1341 & 22 & 15 & & 8.49 & 5.79 \\
1402 & 86 & 20 & & 15.33 & 3.57 \\
1463 & 24 & 21 & & 2.76 & 2.41 \\
1524 & 52 & 54 & & 14.17 & 14.71 \\
1585 & 5 & 28 & & 1.46 & 8.16 \\
1646 & 2 & 12 & & 0.74 & 4.43 \\
1707 & 0 & 0 & & 0 & 0 \\
1768 & 0 & 24 & & 0 & 12 \\
1829 & 8 & 24 & & 1.87 & 5.62 \\
1890 & 1 & 34 & & 0.39 & 13.13 \\
\hline
\end{tabular}

\section{Stratigraphic context}

The Taglu sequence is a deltaic influenced sequence that regionally attains thicknesses in the order of several kilometres (Dietrich et al., 1989; Dixon et al., 1992). The sampled section (Fig. 2) unconformably overlies strata that contain documented evidence of the PETM contained within the upper Paleocene-lower Eocene Aklak sequence. The sampled section also unconformably underlies sediments of the upper Taglu sequence that contain Azolla-rich sediments diagnostic of the acmes of the early middle Eocene Azolla event (McNeil and Parsons, 2013). Well logs and lithological descriptions by Dietrich et al. (1989) indicate that sediments are a relatively uniform silty to pebbly mudstone, but the upper part of the section contains more siltstone. Seismic data interpretations by James R. Dietrich (GSC, personal communication, 2015) indicate that a major unconformity occurs at the base of the section and a minor submarine unconformity occurs at the top. Parallel seismic reflectors through the entire Taglu sequence indicate shelf sedimentation.

Arctic Eocene strata are difficult to date precisely because of the scarcity of chronostratigraphic index fossils. The age of the $H$. apta-bearing stratum is, however, estimated to be approximately 50.5 to $53.0 \mathrm{Ma}$ based on its position above the PETM and below the Azolla acmes).

\section{Results}

Twelve samples from lower Eocene strata in the Natsek E56 exploration well yielded an entirely agglutinated assemblage of foraminifera that was dominated by monothalamous and multi-chambered foraminifera (Fig. 2). One of the monothalamous foraminifera, H. apta $\mathrm{n}$. sp., was found only 


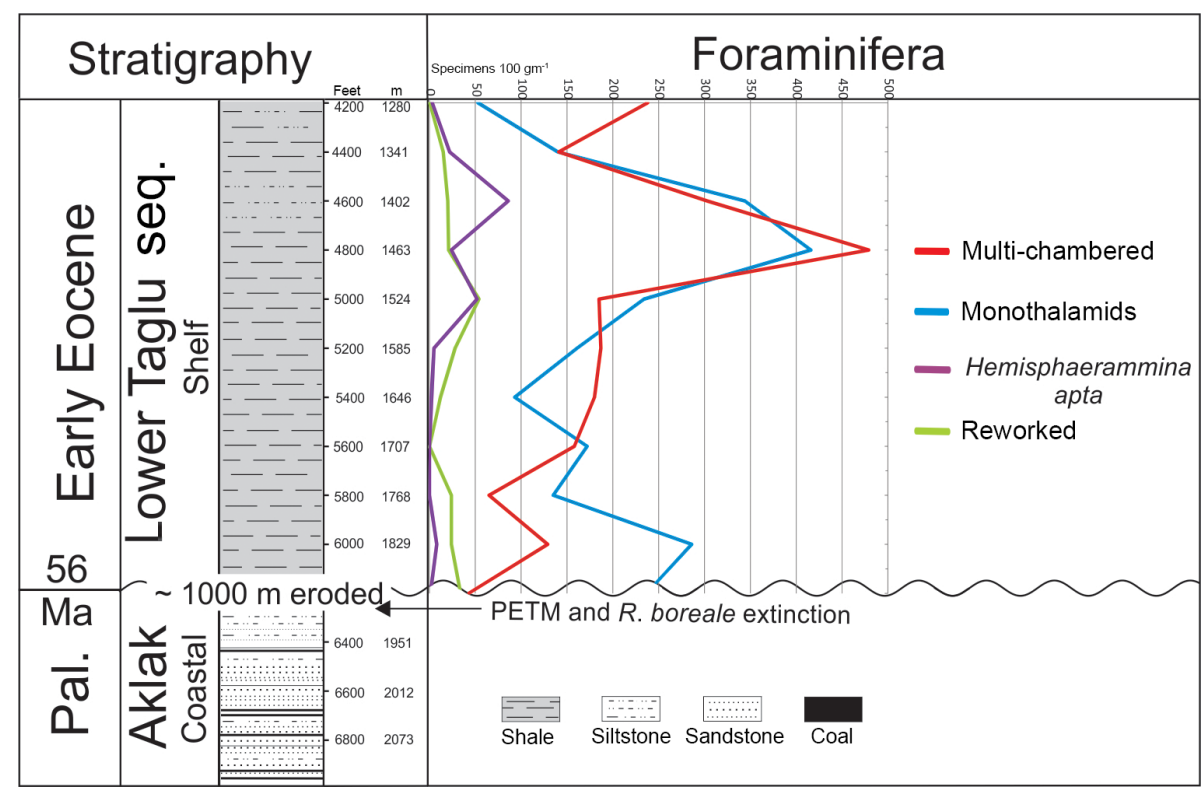

Figure 2. Late Paleocene-early Eocene stratigraphy of the Natsek E-56 well with sample horizons and foraminiferal recovery indicated.

attached to fine detrital grains ( 0.2 to $1.8 \mathrm{~mm}$ in diameter) of mainly chert and quartz (Plates 1 and 2). The shape of the detrital grains varied from rounded to angular. The surface texture was also variable but was usually flattish to convex and smooth to rough. In addition to the in situ microfauna, reworked silicified foraminifera probably of Albian or older age were recovered from all but two of the samples (Fig. 2). One of the reworked foraminifera, a specimen of Glomospira charoides, provided a concave and a convex surface of attachment for H. apta (Plate 2, fig. 4a, b).

The numbers of $H$. apta recovered per sample ranged from 0 to $80(0-15.3 \%$ of total foraminiferal population) with a slight to moderate correlation with associated reworked foraminifera (Table 1). Hemisphaerammina apta occurs in abundance in the upper part of the section from 1524 to $1402 \mathrm{~m}$, with its acme of 80 specimens in the siltier part of the section. Seismic interpretations suggest that the upper part of the section was deposited on the outer shelf (James R. Dietrich, GSC, personal communication, 2015).

\section{Systematic palaeontology}

Order Astrorhizida Lankester, 1885

Suborder Hemisphaeramminineae Loeblich \& Tappan, 1961, emend. Mikhalevich, 1995

Genus Hemisphaerammina Loeblich \& Tappan, 1957

Type species Hemisphaerammina batalleria Loeblich and Tappan, 1957

Hemisphaerammina apta, new species

(Plate 1, figs. 1-3; Plate 2, figs. 1-7)
1964 Ammosphaeroides explanatus Bulatova: 112-113, pl. VII, figs. 3-4.

Description: Test small, unilocular. All specimens firmly attached to fine-sized detrital grains (quartz, chert, rock fragments, and reworked microfossils). No detached specimens were observed. Periphery of test generally circular in plan view with tendency for an irregular margin on rougher attachment surfaces. Test sub-hemispherical in shape, with no floor, no substantive flange, no internal structures, and no aperture. Profile of test varies from concave to convex with majority of specimens irregularly planar. Convex forms may have an incipient flange. Intergranular openings $(\sim 1 \mu \mathrm{m}$ diameter) exist between some grains in the test wall. Wall uniformly fine grained $(\sim 3-6 \mu \mathrm{m})$, thickness approximately $25 \mu \mathrm{m}$. Diameter of test varies from 0.06 to $0.2 \mathrm{~mm}$; height of test varies from 0.04 to $0.10 \mathrm{~mm}$.

Etymology: From the Latin participle aptus meaning fitted to or attached to.

Age, stratigraphy, locality: Early Eocene $(\sim 50.50-$ 53.0 Ma), Taglu sequence, Dome Pacific et al. PEX Natsek N-56 exploration well, Beaufort Sea, Arctic Canada (lat $69^{\circ} 45^{\prime} 21.46^{\prime \prime} \mathrm{N}$, long $139^{\circ} 44^{\prime} 34.58^{\prime \prime} \mathrm{W}$ ).

Material: 203 specimens.

Types: Holotype Geological Survey of Canada (GSC) specimen 1336676, Plate 2, figs. 1a, b, Natsek N-56, 5000 $(1524 \mathrm{~m})$. Holotype and paratypes (Plates 1, 2) curated in the type collection of the Geological Survey of Canada, Calgary. Additional paratypes are deposited in the McNeil Collection 


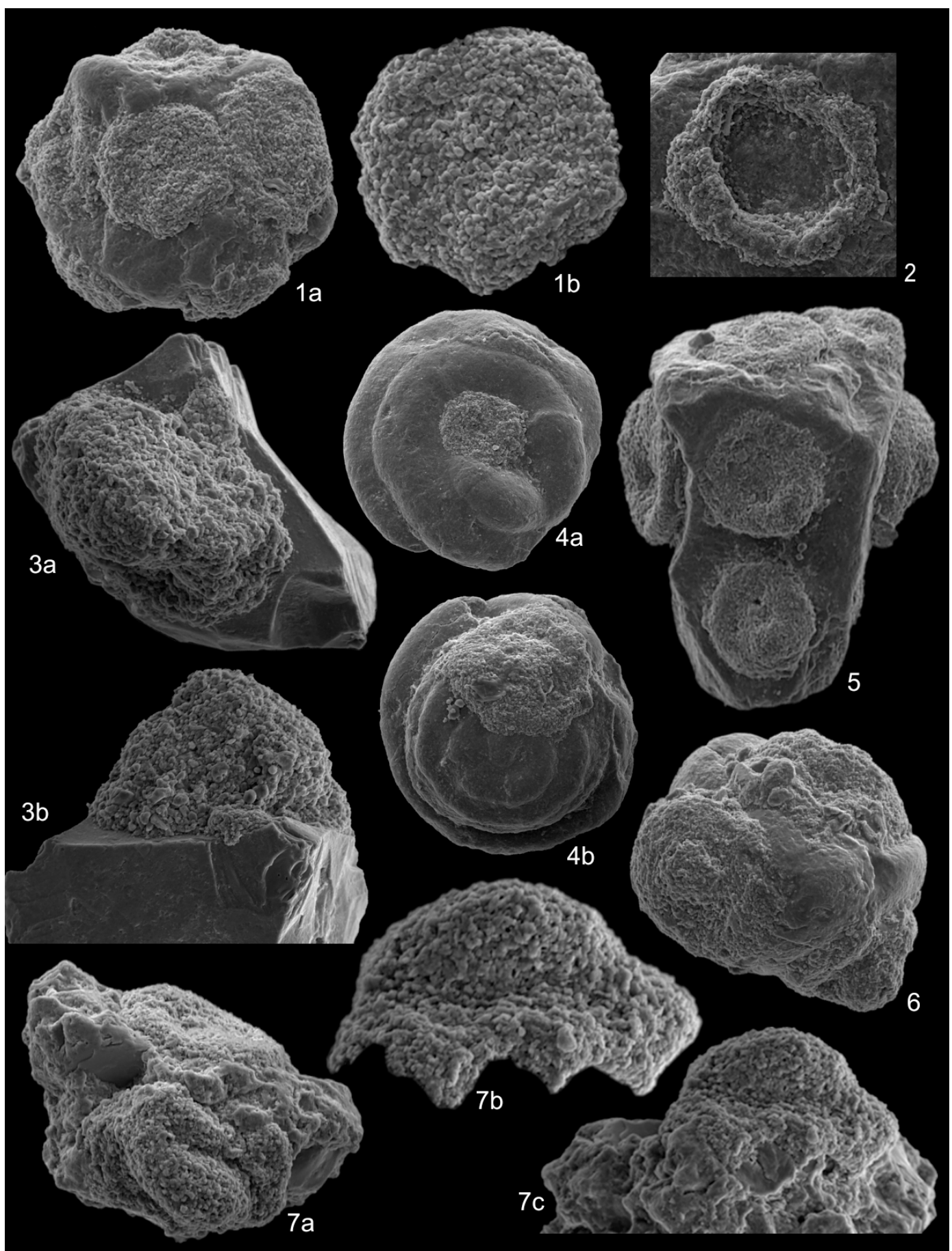

Plate 2. SEM images of Hemisphaerammina apta n. sp. from the Natsek E-56 exploration well, Beaufort Sea, Arctic Canada. (1a, b) Six specimens attached to a sub-rounded detrital grain, $5000 \mathrm{ft}(1524 \mathrm{~m})$ : (1a) holotype (central specimen) GSC 1336676, diameter 134 $\mu$ m; (1b) enlarged view of holotype. (2) Remnant of specimen showing attached wall on detrital grain, $5000 \mathrm{ft}$ (1524 m), paratype GSC 1336677, diameter $141 \mu \mathrm{m}$. (3a, b) Dome-shaped specimen attached to angular quartz grain, $4600 \mathrm{ft}$ (1402 m) paratype GSC 1336678: (3a) dorsal view, maximum diameter $211 \mu \mathrm{m}$; (3b) side view, width $215 \mu \mathrm{m}$, height $156 \mu \mathrm{m}$. (4a, b) Two specimens of $H$. apta attached to a reworked specimen of Glomospira charoides (Jones and Parker), $4300 \mathrm{ft}(1311 \mathrm{~m})$, paratype GSC 1336679, (diameter $313 \mu \mathrm{m})$ : (4a) H. apta (diameter $108 \mu \mathrm{m})$ attached to the umbilical area of G. charoides; (4b) H. apta (diameter $179 \mu \mathrm{m}$ ) attached to the side of G. charoides. (5) Six (of eight) specimens of H. apta attached to sub-angular chert grain (length $588 \mu \mathrm{m}), 4600 \mathrm{ft}(1402 \mathrm{~m})$, paratype (central specimen) GSC 1336673 , diameter $180 \mu \mathrm{m}$. (6) Three specimens of $H$. apta attached to sub-rounded quartz grain, $5000 \mathrm{ft}(1524 \mathrm{~m})$, paratype (specimen on the left) GSC 1336680, diameter $193 \mu \mathrm{m}$. (7a-c) Dome-shaped specimen with irregular margin attached to an irregular-shaped detrital grain, $4200 \mathrm{ft}$ (1280 m), paratype GSC 1336681: (7a) dorsal view; (7b) side view cropped, maximum diameter $136 \mu \mathrm{m} ;(\mathbf{7 c})$ side view. 
at the European Micropalaeontological Reference Centre, Kraków, Poland.

ZooBank registration: urn:1sid:zoobank.org:act:901C1DDB05FC-4B07-BCAD-2A2A943836F3, registered on 2 February 2018.

Remarks: Hemisphaerammina apta was overlooked, or grouped with species of Saccammina, in previous studies of the Beaufort-Mackenzie foraminifera (e.g. Dietrich et al., 1989; McNeil, 1996, fig. 70). It was discovered in the current study because of a more detailed attention to monothalamid foraminifera and a more thorough examination of micropalaeontological samples. Although it is reported here from only one well, its distribution is no doubt more widespread in lower Eocene Arctic strata. It occurs in moderate abundance, as 203 specimens were recovered from 12 samples. It was a small component of the total foraminiferal assemblage, averaging $4.9 \%$ of the total population (Table 1). Relatively high percentages at $1402 \mathrm{~m}$ $(15 \%)$ and $1524 \mathrm{~m}$ might indicate episodes of stronger bottom-water currents.

The majority of specimens conform to a discoidal shape with the central area varying between concave and convex. Variation in the margin of the attachment area might be a response to a more irregular surface of attachment (see Plate 2, fig. $7 \mathrm{a}-\mathrm{c}$ ). Although there were no unattached specimens found, the ventral area can be viewed in specimens attached to clear transparent grains of quartz (Plate 1, figs. 2b, 3b). The chamber lumen in ventral view is coloured light brown, suggesting the presence of residual organic matter. Conkin and Conkin (1981) observed similar dark brown material interpreted as "pseudo-chitin" in the central cavity of $\mathrm{H}$. cecillalickeri from Mississippian strata of the eastern central United States. Some tests from Natsek E-56 have been broken, which provides a view of the area inside the attachment perimeter (Plate 2, fig. 2). These open spaces are assumed to have been caused by abrasion rather than some form of budding.

At least 21 species of Hemisphaerammina, from a long geological history (Silurian to Holocene), have been considered for comparison, but no identical species have come to our attention. The widely recorded recent species $H$. bradyi differs in being much larger, more uniformly hemispheri$\mathrm{cal}$, and containing both fine and coarser agglutinated grains. Other species such as $H$. casteri McClellan, 1966, H. convexa (Cushman), 1919, H. bassensis (Parr), 1945, and H. depressa (Heron-Allen and Earland), 1932 were discounted for a variety of reasons, including differences in convexity, size, wall thickness, wall composition, wall across the attachment area, and the presence of a well-defined marginal flange.

Bulatova (1964) illustrated specimens of $H$. apta from the Hauterivian of Western Siberia. However, Bulatova's "species", Ammosphaeroides explanatus Bulatova, 1964, consisted of two specimens of $H$. apta (misinterpreted as two apertures) attached to a sand grain (misinterpreted as a foraminiferal chamber), hence the use of the genus Ammosphaeroides Cushman, 1910. The genus Ammosphaeroides, however, was deemed invalid by Loeblich Jr. and Tappan (1964) because the type species A. distoma Cushman, 1910, was merely a sand grain with inorganic mineral coatings that gave the appearance of apertures.

\section{Discussion}

Foraminifera are well known for their preferences for specific microhabitats (Poag, 1982; Corliss, 1985; Linke and Lutze, 1993; Alve, 1999; Schönfeld, 2002; Kaminski and Gradstein, 2005). The specificity of microhabit selection is quite remarkable and includes sites as small and inaccessible as the interior of planktonic foraminifera and radiolarians (Gooday et al., 2013; Goineau and Gooday, 2015). H. apta is among those very discerning species when it comes to microhabitat selection, as attachment to fine-sized grains $(0.2-$ $1.8 \mathrm{~mm}$ ) was a requirement. It does not, however, appear to have been very selective in regard to what type of grain it attaches to. Grains are mostly of quartz or chert, light to dark in colour and have rough to smooth surfaces. Hemisphaerammina apta may have had an ability to select its location of attachment. For example, its position centred on the concave umbilical area of a reworked specimen of Glomospira charoides (Plate 2, fig. 4a, b). Logically, a concave area would provide protection from abrasive damage. However, most examples of $H$. apta attachment appear to be random on a variety of surfaces that are flat, gently concave, or convex. Most grains do not have such a tidy concavity as does Glomospira, so given more chances $H$. apta might show more examples of site selection. Meadows and Anderson (1968) observed that micro-organisms such as bacteria, algae, and diatoms attached to sand grains had a preference for concave areas. Attachment to grains in terms of rock type and surface selection appears to be random. The occurrence of bacteria, algae, and diatoms on the grains (Meadows and Anderson, 1968) would provide an immediate food source for the newly attached $H$. apta.

The occurrence of H. apta in the lower Eocene is an element of the recolonization of benthic foraminifera after the climatic changes of the PETM when the majority of the benthic foraminifera in the Arctic shelf environments went extinct (McNeil and Parsons, 2013). Recolonization of the Arctic Ocean shelves occurred through the introduction of new assemblages of agglutinated foraminifera dominated by monothalamids and low-diversity multi-chambered assemblages. The populations reflect relative isolation, restricted circulation, low salinity, and an active hydrological system. Hemisphaerammina apta would be an opportunistic species entering the basin during the early Eocene when a major transgression deposited the first sediments of the thick deltaic Taglu sequence. The fact that $H$. apta occurs on fine sedi- 
ment grains probably reflects the regular episodes of sea floor disturbance and winnowing brought on by storm events during the rapidly changing climate of the early Eocene (Barron et al., 1989; Brinkhuis et al., 2006; Pagani et al., 2006; Sluijs et al., 2006). The seafloor disturbance therefore required $H$. apta to attach as a means of stability. It occurs more or less consistently over $670 \mathrm{~m}$ of section indicating that favourable microhabitats for reproduction existed for a considerable amount of time $(\sim 2 \mathrm{Ma})$.

As H. apta does not have an aperture, it must have communicated with the surrounding environment through interstitial openings in its agglutinated test. Small openings are visible in scanning electron microscope (SEM) images (Plate 2, figs. 1b, 7b). The openings are likely used for feeding and propagation, among other things. Pseudopodia would have had access to predate on other organisms on the sand grain and to particles in suspension. Propagation would have occurred by the release of minute biflagellate gametes or propagules (Alve and Goldstein, 2003, 2010) that were mobile, passively dispersed, and then attached to neighbouring sand grains. Although the majority of specimens were individuals on individual grains, they were also capable of densely colonizing individual grains (Plate 1, fig. 1; Plate 2, figs. 5-7).

\section{Summary}

Hemisphaerammina apta is newly described from the continental margin of the early Eocene Arctic Ocean. Associated foraminifera are entirely agglutinated and distinguished by an abundance of monothalamous specimens constituting up to $60 \%$ of the populations. Hemisphaerammina apta stands apart from associated foraminifera because of its highly specialized microhabitat of attachment to fine grains of sand. In addition to in situ foraminifera, the assemblages contain abundant specimens of reworked foraminifera (up to $14.7 \%$ of the total foraminiferal population). The abundance of reworked foraminifera and attached $H$. apta suggest an unstable substrate with $H$. apta clinging to fine grains to minimize transportation and increase stability. This is consistent with previous interpretations of an active hydrological system for the early Eocene Arctic and a high potential for storm events that would disturb Arctic margin substrates.

Data availability. Data to support Fig. 2 are archived in McNeil (2018). This unpublished palaeontological report can be obtained by contacting the Geological Survey of Canada (Calgary).

Competing interests. The authors declare that they have no conflict of interest.
Acknowledgements. We thank Michael A. Kaminski (King Fahd University of Petroleum and Minerals), Eiichi Setoyama (Energy and Geoscience Institute, University of Utah), and Jennifer G. Galloway (Geological Survey of Canada, Calgary) for providing constructive comments on the manuscript. Seismic interpretations relevant to the Taglu sequence by James R. Dietrich (Geological Survey of Canada, Calgary) are gratefully acknowledged. Scanning electron images of $H$. apta were provided by W. Michael Schoel of the University of Calgary's Department of Cell Biology and Anatomy. This research was supported by the Geological Survey of Canada's Geo-mapping for Energy and Minerals Program. This is Geological Survey of Canada, Earth Sciences contribution 20170032.

Edited by: Sev Kender

Reviewed by: Michael A. Kaminski and Eiichi Setoyama

\section{References}

Alve, E.: Colonization of new habitats by benthic foraminifera: a review, Earth-Sci. Rev., 46, 167-185, https://doi.org/10.1016/S0012-8252(99)00016-1, 1999.

Alve, E. and Goldstein, S. T.: Propagule transport as a key method of dispersal in benthic foraminifera (Protista), Limnol. Oceanogr., 48, 2163-2170, https://doi.org/10.4319/lo.2003.48.6.2163, 2003.

Alve, E. and Goldstein, S. T.: Dispersal, survival and delayed growth of benthic foraminiferal propagules, J. Sea Res., 63, 3651, https://doi.org/10.1016/j.seares.2009.09.003, 2010.

Barron, E. J., Hay, W. W., and Thompson, S.: The hydrologic cycle: A major variable during Earth history, Glob. Planet. Change, 1, 157-174, https://doi.org/10.1016/0031-0182(89)90175-2, 1989.

Brinkhuis, H., Schouten, S., Collinson, M., Sluijs, A., Sinninghe Damste, J. S., Dickens, J. R., Huber, M., Cronin, T. M., Onodera, J., Takahashi, K., Bujak, J. P., Stein, R., van der Burgh, J., Eldrett, J., Harding, I. C., Lotter, A. F., Sangiorgi, F., van Konijnenburgvan Cittert, H., de Leeuw, J. W., Matthiessen, J., Backman, J., Moran, K., and the Expedition 302 Scientists: Episodic fresh surface waters in the Eocene Arctic Ocean, Nature, 441, 606-609, https://doi.org/10.1038/nature04692, 2006.

Bulatova, Z. I.: Order Astrorhizidae, in: Foraminifera of Cretaceous and Paleocene Deposits of Western Siberian Lowlands, edited by: Subbotina, N. N., Transactions of the All-Union PetroleumScientific Research Geology Prospecting Institute (VNIGRI), Leningrad, 77-143, 1964.

Cherchi, A. and Schroeder, R.: Middle Cambrian foraminifera and other microfossils from SW Sardinia, Bollettino della Società Paleontologica Italiana, 23, 149-160, 1985.

Conkin, J. E. and Conkin, B. M.: A revision of some Upper Devonian foraminifera from Western Australia, Palaeontology, 11, 601-609, 1968.

Corliss, B. H.: Microhabitats of benthic foraminifera within deep-sea sediments, Nature, 314, 435-438, https://doi.org/10.1038/314435a0, 1985.

Cushman, J. A.: A monograph of the Foraminifera of the North Pacific Ocean. United States National Museum, Bulletin 71, (a) Part 1. Astrorhizidae and Lituolidae, 134 p., 1910. 
Cushman, J. A.: A new foraminifer commensal on Cyclammina, U.S. National Museum, Proceedings, Washington, D.C., USA, 2290, 56, 101-102, 1919.

Dietrich, J. R., Dixon, J., McNeil, D. H., McIntyre, D. J., Snowdon, L. R., and Cameron, A. R.: The geology, biostratigraphy, and organic geochemistry of the Natsek E-56 and Edlok N-56 wells, western Beaufort Sea, Geological Survey of Canada, Paper 891G, 133-157, https://doi.org/10.4095/127588, 1989.

Dixon, J., Dietrich, J. R., and McNeil, D. H.: Upper Cretaceous to Pleistocene sequence stratigraphy of the Beaufort-Mackenzie and Banks Island areas, northwest Canada, Geological Survey of Canada, Bulletin 407, 90 p., 1992.

Goineau, A. and Gooday, A. J.: Radiolarian tests as microhabitats for novel benthic foraminifera: Observations from the abyssal eastern equatorial Pacific (ClarionClipperton Fracture Zone), Deep-Sea Res. I, 103, 73-85, https://doi.org/10.1016/j.dsr.2015.04.011, 2015.

Goldstein, S. T.: Morphology, molecules, and the monothalamous Foraminifera: Overview of works in progress, in: International Symposium on Foraminifera FORAMS 2014, edited by: Marchant, T. and Hromic, T., Chile, 19-25 January 2014, Abstract Volume, Grzybowski Foundation Special Publication, 20, $1,2014$.

Gooday, A. J., Rothe, N., and Pearce, R. B.: New and poorly known benthic foraminifera (Protista, Rhizaria) inhabiting the shells of planktonic foraminifera on the bathyal Mid-Atlantic Ridge, Mar. Biol. Res., 9, 447-461, https://doi.org/10.1080/17451000.2012.750365, 2013.

Guilbault, J.-P., Krautter, M., Conway, K. W., and Barrie, J. V.: Modern foraminifera attached to hexactinellid sponge meshwork on the west Canadian shelf: comparison with Jurassic counterparts from Europe, Palaeontologica Electronica, 9, 1-48, 2006.

Heron-Allen, E. and Earland, A.: Foraminifera; Part I - The icefree area of the Falkland Islands and adjacent seas, Discovery Reports, Cambridge, University Press, 4, 291-460, 1932.

Jonasson, K. E. and Schröder-Adams, C. J.: Encrusting agglutinated foraminifera on indurated sediment at a hydrothermal venting area on the Juan de Fuca Ridge, Northeast Pacific Ocean, J. Foramin. Res., 26, 137-149, https://doi.org/10.2113/gsjfr.26.2.137, 1996.

Kaminski, M. A. and Gradstein, F. M.: Atlas of Paleogene Cosmopolitan Deep-Water Agglutinated Foraminifera, Grzybowski Foundation Special Publication, 10, 547 p., 2005.

Langer, M. R.: Epiphytic foraminifera, Mar. Micropaleontol., 20, 235-265, https://doi.org/10.1016/0377-8398(93)90035-V, 1993.

Langer, M. R. and Bagi, H.: Tubicolous polychaetes as substrates for epizoic foraminifera, J. Micropalaeontol., 13, 132132, https://doi.org/10.1144/jm.13.2.132, 1994.

Langer, M. R. and Long, D. J.: Association of benthic foraminifera with a gammarid amphipod on tidal flats of San Francisco Bay, California, J. Coastal Res., 10, 877-883, 1994.

Lankester, E. R.: Protozoa, in: Encyclopaedia Britannica, 19, 9th ed., 830-866, 1885.

Le Calvez, J.: Recherches sur les foraminifères. 1. Développement et reproduction. Archives de Zoologie Expérimentale et Générale, 80, 163-333, 1938.

Linke, P. and Lutze, G. F.: Microhabitat preferences of benthic foraminifera - a static concept or a dynamic adaptation to op- timize food acquisition?, Mar. Micropaleontol., 20, 215-234, https://doi.org/10.1016/0377-8398(93)90034-U, 1993.

Loeblich Jr., A. R. and Tappan, H.: Eleven new genera of foraminifera, Bulletin of the United States National Museum, 215, 223-232, https://doi.org/10.1007/978-1-4899-57603, 1957.

Loeblich Jr., A. R. and Tappan, H.: Suprageneric classification of the Rhizopodea, J. Paleontol., 35, 245-330, 1961.

Loeblich Jr., A. R. and Tappan, H.: Sarcodina Chiefly "Thecamoebians" and Foraminiferida, in: Treatise on Invertebrate Paleontology, edited by: Moore, R. C., Part C, Protista 2, 900 p., 1964.

Loeblich Jr., A. R. and Tappan, H.: Foraminiferal Genera and Their Classification, Van Nostrand Reinhold Company, New York, 970 p., 1988.

McClellan, W. A.: Arenaceous foraminifera from the Waldron Shale (Niagaran) of southeast Indiana, Bulletin of American Paleontology, 50, 447-518, 1966.

McNeil, D. H.: Distribution of Cenozoic agglutinated benthic foraminifers in the Beaufort-Mackenzie Basin, in: Geological Atlas of Beaufort-Mackenzie Basin, edited by: Dixon, J., Geological Survey of Canada, Miscellaneous Report, 59, 105-106, https://doi.org/10.4095/207695, 1996.

McNeil, D. H.: New Foraminifera from the Upper Cretaceous and Cenozoic of the Beaufort-Mackenzie Basin of Arctic Canada. Cushman Foundation for Foraminiferal Research, Special Publication No. 35, 95 p., 1997.

McNeil, D. H.: Foraminifera (early Eocene) from the Dome Pacific et al. PEX Natsek E-56 exploration well (4200 to $6200 \mathrm{ft}$; 1280 $1890 \mathrm{~m})$, Beaufort Sea $\left(69^{\circ} 45^{\prime} 21.46^{\prime \prime} \mathrm{N} ; 139^{\circ} 44^{\prime} 34.58^{\prime \prime} \mathrm{W}\right)$, Arctic Canada, Geological Survey of Canada, Paleontological Report, DHM-2018-01, 3 p., 2018.

McNeil, D. H. and Parsons, M. G.: The Paleocene-Eocene thermal maximum (PETM) in the Beaufort-Mackenzie Basin - Palynomorphs, carbon isotopes, and benthic foraminiferal turnover, B. Can. Petrol. Geol., 61, 157-186, https://doi.org/10.2113/gscpgbull.61.2.157, 2013.

Meadows, P. S. and Anderson, J. G.: Micro-organisms attached to marine sand grains, J. Mar. Biol. Assoc. UK, 48, 161-175, https://doi.org/10.1017/S0025315400032501, 1968.

Mikhalevich, V. I.: A new classification of the class Astrorhizata (Foraminifera), Zoosystematica Rossica, 3, 161-174, 1995.

Mikhalevich, V. and Debenay, J.-P.: The main morphological trends in the development of the foraminiferal aperture and their taxonomic significance, J. Micropalaeontol., 20, 13-28, https://doi.org/10.1144/jm.20.1.13, 2001.

Pagani, M., Pedentchouk, N., Huber, M., Sluijs, A., Schouten, S., Brinkhuis, H., Sinninghe Damsté, J. S., Dickens, G. R., and Expedition 302 Scientists: Arctic hydrology during global warming at the Palaeoecene/Eocene thermal maximum, Nature, 442, 671675, https://doi.org/10.1038/nature05043, 2006.

Parr, W. J.: Recent foraminifera from Barwon Heads, Victoria, Royal Society of Victoria, Proceedings, Melbourne, 1945, 56, 189-218, 1945.

Plint, A. G., Jin, J., Varban, B. L., and Rylaarsdam, J. R.: A highlatitude epilithozoan fauna on quartzite clasts and the problem of cobble transport across a coastal plain: middle Turonian Kaskapau Formation, British Columbia, Canada, Palaios, 21, 557-570, https://doi.org/10.2110/palo.2006.p06-042r, 2006. 
Poag, W. C.: Environmental implications of test-to-substrate attachment among some modern sublittoral foraminifera, Geol. Soc. Am. Bull., 93, 252-268, https://doi.org/10.1130/00167606(1982)93<252:EIOTAA>2.0.CO;2, 1982.

Radford, D., Walker, S. E., and Bowser, S. S.: Alpha and beta diversity of foraminifera that encrust the Antarctic scallop Adamussium colbecki: ecological connectivity among shells and between sites, J. Foramin. Res., 44, 255-280, https://doi.org/10.2113/gsjfr.44.3.255, 2014.

Resig, J. M. and Glenn, C. R.: Foraminifera encrusting phosphoritic hardgrounds of the Peruvian upwelling zone: taxonomy, geochemistry, and distribution, J. Foramin. Res., 27, 133-150, https://doi.org/10.2113/gsjfr.27.2.133, 1997.

Richardson-White, S. and Walker, S. E.: Diversity, taphonomy and behavior of encrusting foraminifera on experimental shells deployed along a shelf-to-slope bathymetric gradient, Lee Stocking Island, Bahamas, Palaeogeogr. Palaeocl., 312, 305-324, https://doi.org/10.1016/j.palaeo.2011.02.021, 2011.
Sluijs, A., Schouten, S., Pagani, M., Woltering, M., Brinkhuis, H., Damste, J. S. S., Dickens, G. R., Huber, M., Reichart, G.-J., Stein, R., Matthiessen, J., Lourens, L. J., Pedentchouk, N., Backman, J., Moran, K., and the Expedition 302 Scientists: Subtropical Arctic Ocean temperatures during the Palaeocene/Eocene thermal maximum, Nature, 441, 610-613, https://doi.org/10.1038/nature04668, 2006.

Schönfeld, J.: Recent benthic foraminiferal assemblages in deep high-energy environments from the Gulf of Cadiz (Spain), Mar. Micropaleontol., 44, 141-162, https://doi.org/10.1016/S03778398(01)00039-1, 2002. 